Terr. Atmos. Ocean. Sci., Vol. 17, No. 4, 703-722, December 2006

\title{
Distribution of Gassy Sediments and Mud Volcanoes Offshore Southwestern Taiwan
}

\author{
Jui-Kun Chiu ${ }^{1}$, Wei-Hao Tseng ${ }^{1}$, and Char-Shine Liu ${ }^{1}{ }^{1}$ *
}

(Manuscript received 31 October 2005, in final form 28 April 2006)

\begin{abstract}
This study presents the results from recent intense marine geophysical surveys conducted offshore of southwestern Taiwan. Mud volcanoes and gassy sediments have been identified along chirp sonar and seismic reflection profile data. The distribution of gassy sediments and mud volcanoes has been compiled, showing these features extending from the accretionary wedge to the passive China continental margin. Submarine mud volcanoes could be grouped into four main clusters in the accretionary wedge province: offshore Kaohsiung, adjacent to the Kaoping Submarine Canyon, near the head of the Fangliao Submarine Canyon and along the Yung-An Lineament. Each cluster is composed of a few to more than 10 submarine mud volcanoes. Their origin could be related to gas hydrate dissociation with rising highpressure fluid along faults or mud diapir piercing the seafloor. These gassy sediments and mud volcanoes could be formed by fluids escaping from dewatering sedimentary layers of mud diapirs, or along faults and fractures where free gases or gases dissociating from hydrates migrate to the seafloor.
\end{abstract}

(Key words: Gassy sediment, Mud volcano, Fluid migration, Offshore southwestern Taiwan)

\section{INTRODUCTION}

The occurrence of gassy sediments and submarine mud volcanoes has been reported in both coastal and deep-water environments (Yun et al. 1999; Fleischer et al. 2001; Lee and Chough 2003). The origin of gassy sediments has been attributed to the upward migration of biogenic and/or thermogenic gases from deeper parts of sedimentary layers (Lee and Chough 2003; Oung et al. 2006). Submarine mud volcanoes are created by lateral tectonic compres-

\footnotetext{
${ }^{1}$ Institute of Oceanography, National Taiwan University, Taipei, Taiwan, ROC

* Corresponding author address: Prof. Char-Shine Liu, Institute of Oceanography, National Taiwan University, Taipei, Taiwan, ROC; E-mail: csliu@ntu.edu.tw
} 
sion with gas/fluid upward migration (Milkov 2000). Gassy sediments and submarine mud volcanoes are the most common pathways that methane, the predominant gas in marine sediments, migrates from the seabed into the atmosphere (Dimitrov 2002). They become increasingly important in global studies of gas hydrates and climate change.

On the upper continental slope of the Gulf of Mexico, active gas migrations along faults or at mud volcanoes have been identified and their sources attributed to accumulated gas hydrates (Sassen et al. 2001; MacDonald et al. 2003). Milkov (2000) estimated that methane accumulated in gas hydrate associated with mud volcanoes is about $10^{10}-10^{12} \mathrm{~m}^{3}$ at normal temperature and pressure. Judd (1997) estimated that up to $40 \%$ of total United Kingdom methane emission was from the continental shelf around UK. It is therefore important to investigate marine gassy sediments and submarine mud volcanoes to better understand the dynamics of shallow-water methane transport, fluid migration and the relationship of these phenomena to gas hydrate.

The area offshore of southwestern Taiwan, where the Luzon subduction system meets with the passive China continental margin, has received large amounts of sediments from the Taiwan mountain belt (Covey 1984; Milliman and Kao 2005) and is tectonically very active (Huang et al. 1997; Lacombe et al. 2001; Liu et al. 1997, 1998, 2004). The natural environment is suitable for methane production and emission. Many on-land mud volcanoes have been found in southern Taiwan (Yang et al. 2004). Gassy sediments and submarine mud volcanoes have been observed in this area (Liu et al. 1997), but before now there has been no systematic attempt to map their distribution. In the last few years, intensive marine geophysical surveys have been carried out to investigate gas hydrate distribution and its properties in this region (Liu et al. 2006); a dense grid of seismic reflection and chirp sonar profile data have been collected. We have examined this dataset together with previously collected $3.5 \mathrm{kHz}$ and seismic reflection profiles (Fig. 1), and have identified many mud volcanoes and gassy sediments from the available geophysical datasets. This paper presents the results of our efforts to map the distribution of gassy sediments and submarine mud volcanoes offshore southwestern Taiwan that appear in different geological settings, including shelf, slope, submarine canyons, intra-slope basins and deep-sea basins.

\section{GEOLOGICAL SETTING}

The area offshore of southwestern Taiwan is the place where the passive China continental margin meets the Taiwan mountain belt (Liu et al. 1997). Therefore, there are two distinctive tectonic provinces in this area: the passive China continental margin, and the submarine Taiwan accretionary wedge, separated by a deformation front (Fig. 2). The structural patterns are quite different in these two provinces: ENE-WSW trending normal faults are observed in the passive continental margin province located in the western part of the study area, while fold-and-thrust structures are the dominant features in the accretionary wedge province to the east. Complex systems of mud diapirs are observed in the Kaoping shelf and slope area (Sun and Liu 1993)

Morphologically, the passive China continental margin consists of the South China Sea Shelf, South China Sea Slope and a continental rise at the foot of the slope (Liu et al. 1998). 
The South China Sea Shelf is the southwestward extension of the Taiwan Strait Shelf. It is shallow and relatively flat, and has a width of about $200 \mathrm{~km}$. The South China Sea Slope presents different slope gradients and topography, marked by submarine gullies and canyons. The deformation front is represented by the lower Penghu Submarine Canyon in the south, and the boundary between the South China Sea slope and the north termination of anticlinal ridges (Liu et al. 2004). East of the deformation front, the accretionary wedge province consists of the Kaoping Shelf and Kaoping Slope. The Kaoping Shelf is a narrow and shallow shelf that is the seaward prolongation of the coastal plain of southwestern Taiwan. The Kaoping Slope with a very irregular surface can be divided into upper and lower slope domains. The upper slope domain has NE-SW trending gullies and submarine canyons, while the lower slope domain is characterized by closely spaced N-S to NW-SE trending ridges and troughs formed by structural deformation and surface erosion (Yu and Song 2000).

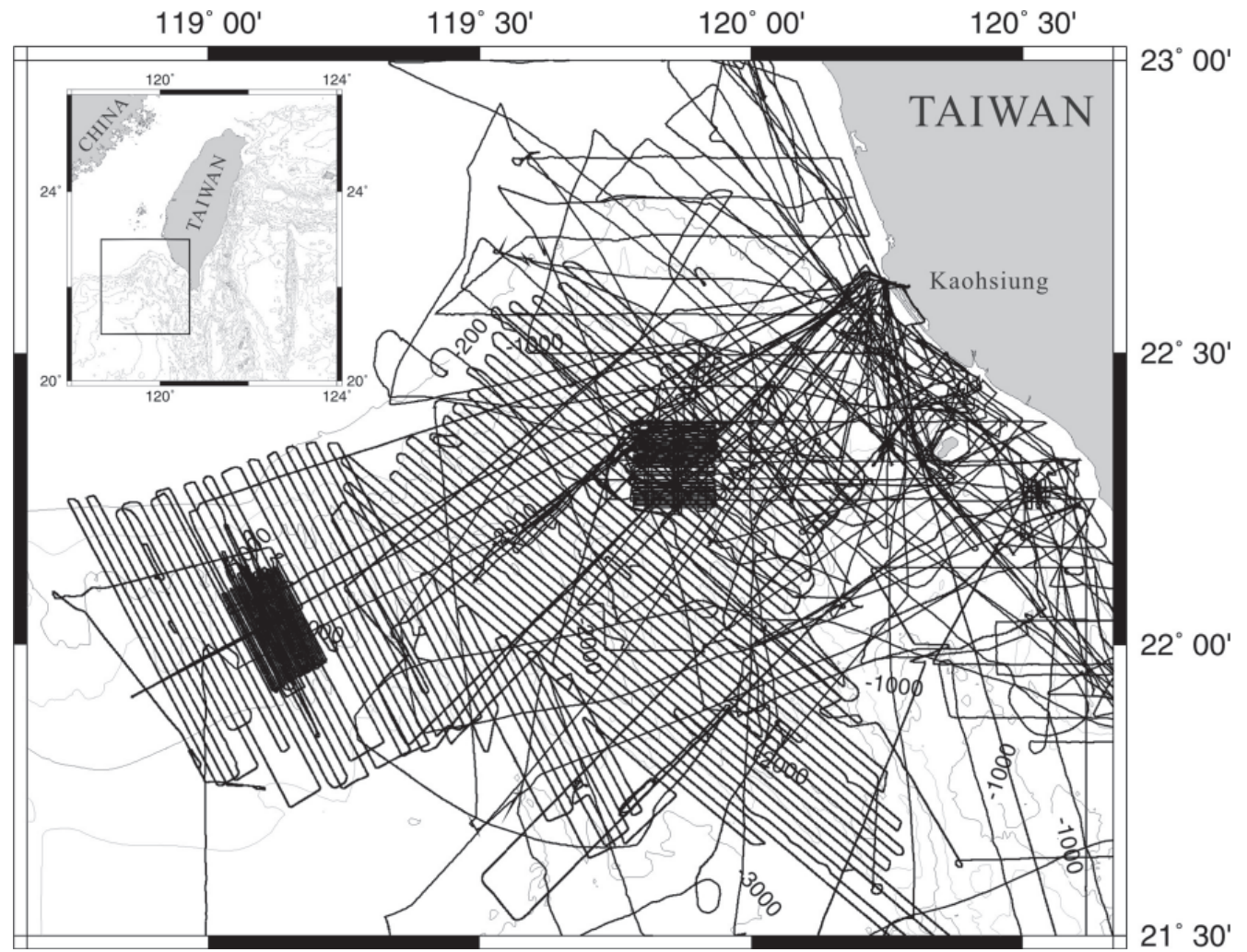

Fig. 1. Distributions of the survey lines used in this study offshore of southwestern Taiwan. Data include chirp sonar profiles and $3.5 \mathrm{kHz}$ sub-bottom profiles. The location of the study area is shown in the upper left inlet. 


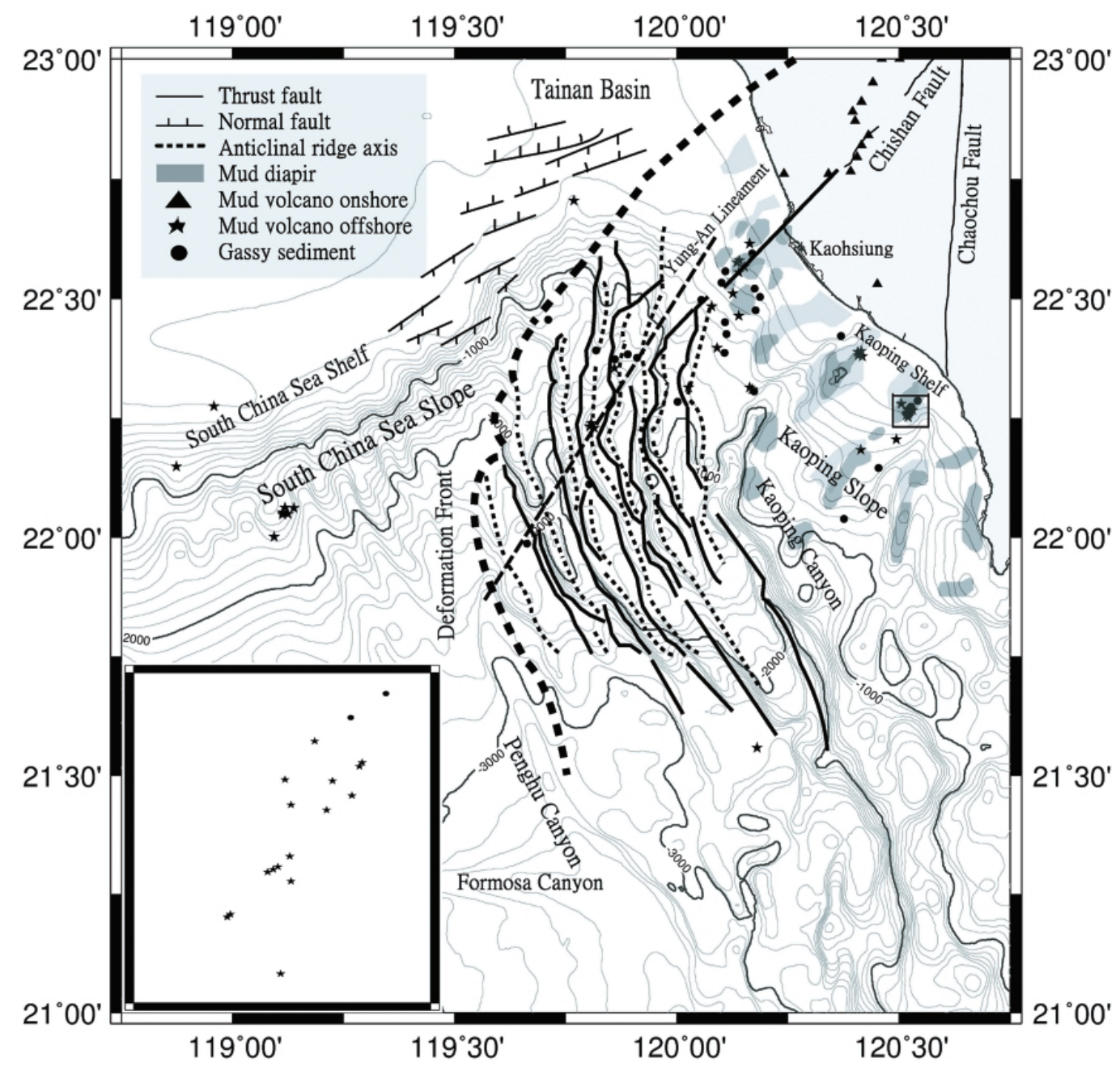

Fig. 2. The distribution map of gassy sediments and mud volcanoes. Inlet is the enlarged map showing a cluster of mud volcanoes (boxed dots) near the head of the Fangliao Canyon. The shaded zone pitched the mud diapirs described in the text. The deformation front (dashed thick line) separates the accretionary wedge province from the passive China continental margin province.

Since the Pliocene, large amounts of sediments derived from the Taiwan mountain belt have been transported to offshore southwestern Taiwan due to rapid tectonic uplift and high erosion rates (Covey 1984). The Kaoping River, the largest river in southern Taiwan, dis- 
charges of about $3.6 \times 10^{7} \mathrm{Mt}$ of fine-grained sediment annually to the offshore region of southwestern Taiwan (Water Resources Bureau 1998).

\section{METHODS}

\subsection{Data Acquisition and Processing}

The datasets used in this study consist of multi-channel seismic (MCS) reflection and sub-bottom profiler (SBP) data. Approximately 10000 kilometers of MCS and SBP profile data were analyzed in this study (Fig. 1). Those data were collected by the R/V Ocean Research I (ORI) from 1990 to 2005. Most of the survey lines for gas hydrate investigation are oriented in a WNW-ESE direction with a line interval of about $1.86 \mathrm{~km}$. There are two small blocks where seismic surveys have been conducted with 400-m line spacing. The SBP data were collected by a hull-mounted $3.5 \mathrm{kHz}$ system before 2001 . That system was replaced by a hull-mounted Bathy-2000P chirp sonar profiler system after 2002. So SBP data used in this study consists of both $3.5 \mathrm{kHz}$ analog profiles and digital chirp sonar profile data. The Bathy2000P is a chirp sub-bottom profiling system using an $8 \mathrm{kHz}$ bandwidth FM chirp waveform. The system could provide 8 -cm resolution sub-bottom profiles of sediment strata with bottom penetration up to 200 meters in an ideal environment. It is designed for applications in rivers, harbors, and coastal waters, and performs to depths of 6000 meters.

The MCS data were collected using a multi-channel seismic data acquisition system onboard OR 1 that consists of a 24- to 48-channel solid streamer, a 3-airgun source array (about $550 \mathrm{in}^{3}$ in total column), and the DFS-V recording system. The MCS data were processed using the ProMAX interactive seismic data processing system. The processing sequences follow that suggested by Yilmaz (1987).

The advantage of combined analyses of both SBP and co-collected seismic reflection profiles is that we could have a clear image from the seafloor to deeper parts of the strata. The sub-bottom profiler could acquire high-resolution data, but the penetration is limited to 200 meters and usually much less. Seismic reflection images could cover the deeper parts of the strata, but the resolution is not as good as the sub-bottom profiler. Combining analyses of these two types of data could help us to obtain a better understanding of the structure and origin of the gassy sediments and submarine mud volcanoes identified in this study.

\subsection{Identification of Gassy Sediments}

Gassy sediments and mud volcanoes contain free gases. Free gas is known to produce impedance contrasts between gassy sediments and the surrounding gas-free strata that generate the distinctive acoustic characters of the seafloor, such as blank zones, bright reflectors, etc. These special acoustic characters could easily be identified on the SBP and high-resolution seismic reflection images. We present some examples bellow, and the locations of these examples are shown in Fig. 3.

The presence of large amounts of free gas within the sediments results in absorption of most of the high-frequency acoustic energy, producing a shielding effect and an anomalous 
reflection-free zone immediately below on SBP images. The acoustic blanking with a sharp boundary could be easily identified on the chirp sonar profiles (Fig. 4a) and $3.5 \mathrm{kHz}$ subbottom profiles (Fig. 5a), especially where sediments are well-stratified.

\subsection{Identification of Submarine Mud Volcanoes}

Submarine mud volcanoes are identified in the sub-bottom profilers as dome structures of convex-upward geometry; the width of a typical mud volcano is 100 - 200 meters, and rises to 15 - 50 meters above the surrounding seafloor. The parallel reflectors of the sediments around mud volcanoes were clearly bent, and the mud volcanoes are generally accompanied by columnar acoustic blanking, caused by fluid upward migration. In the MCS profiles, what we observed are the disturbed and enhanced sub-horizontal and parallel reflectors of the sediments in columnar shape. They are the indicators of feeder channels, the paths of upward migration of gases or pore fluids in submarine mud volcanoes.

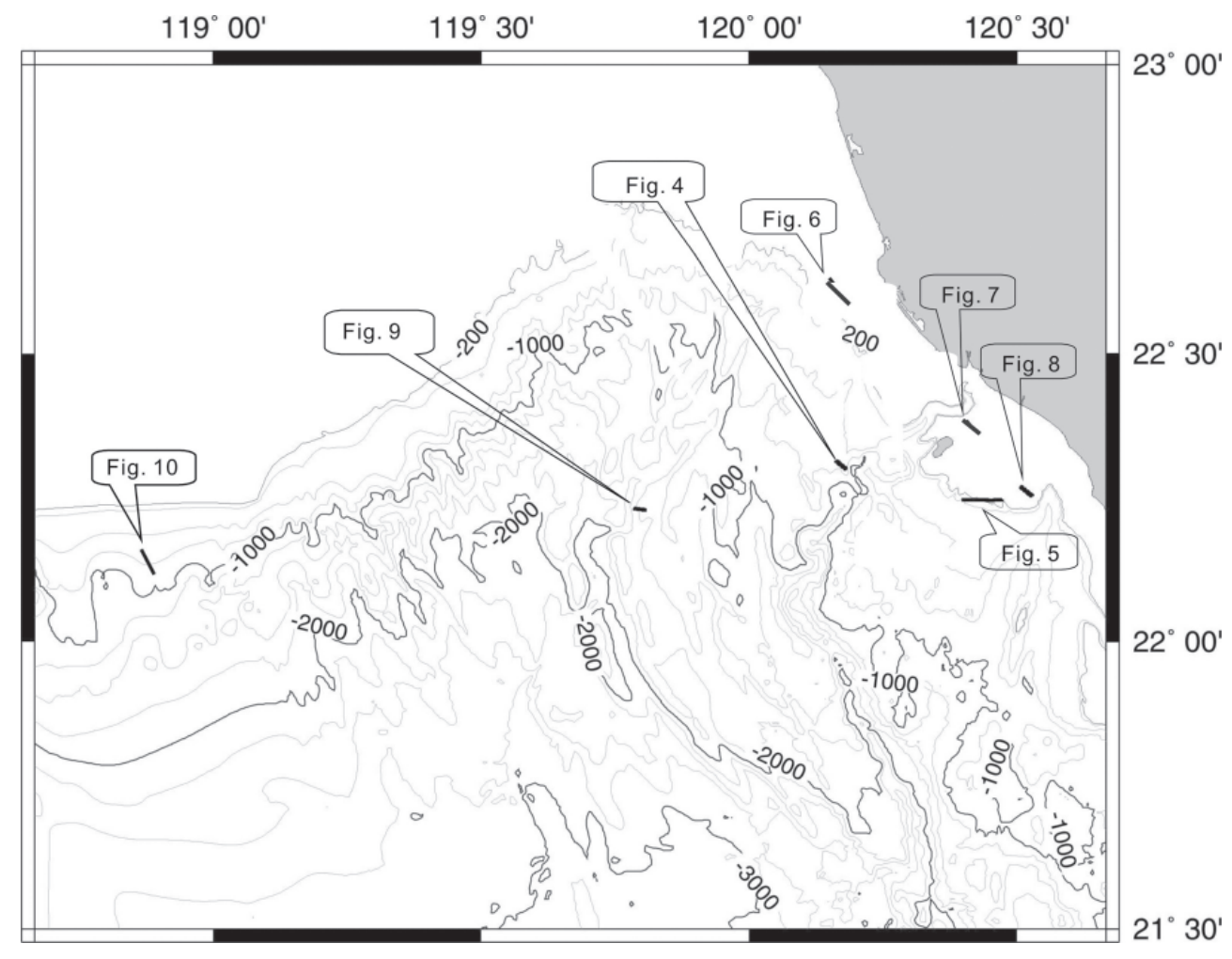

Fig. 3. Map shows the locations of the profiles used as examples in this paper. The bold lines indicate the actual locations of profiles in the specified figures. 
(a)

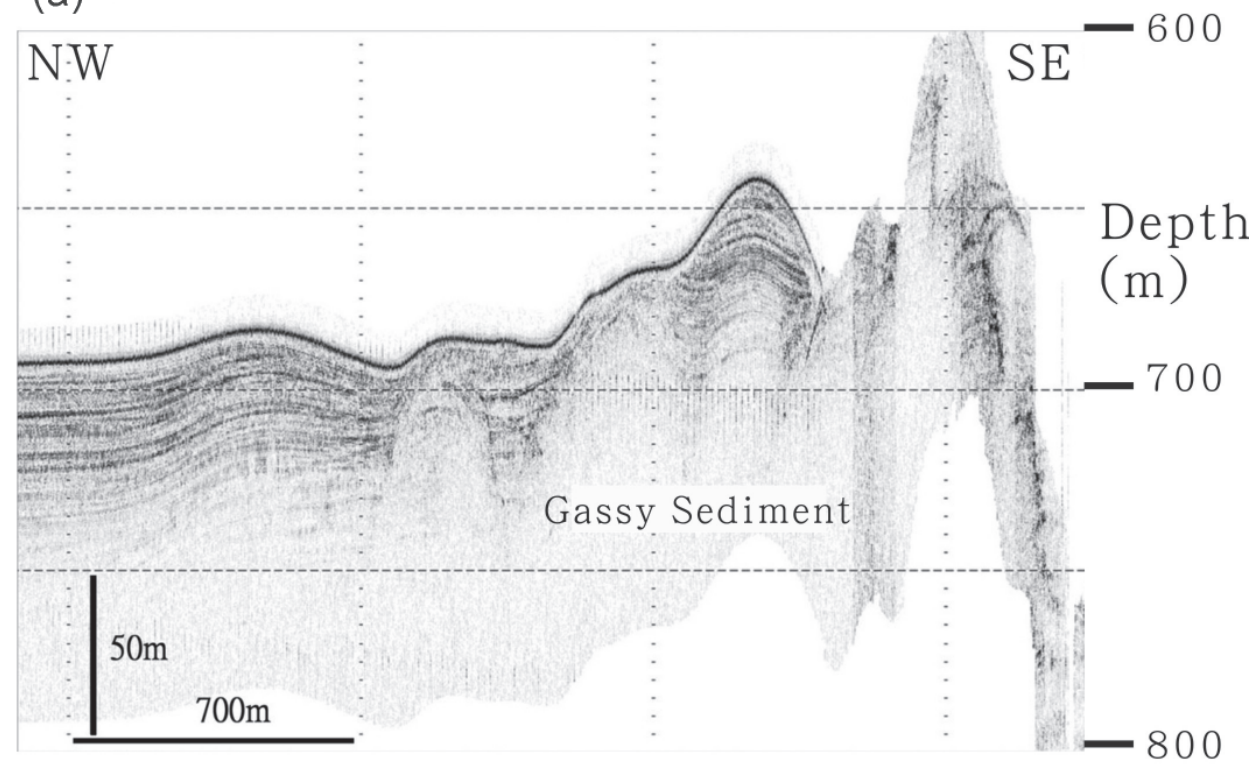

(b)

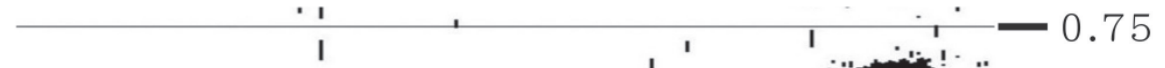

Seismic Blanking Zone
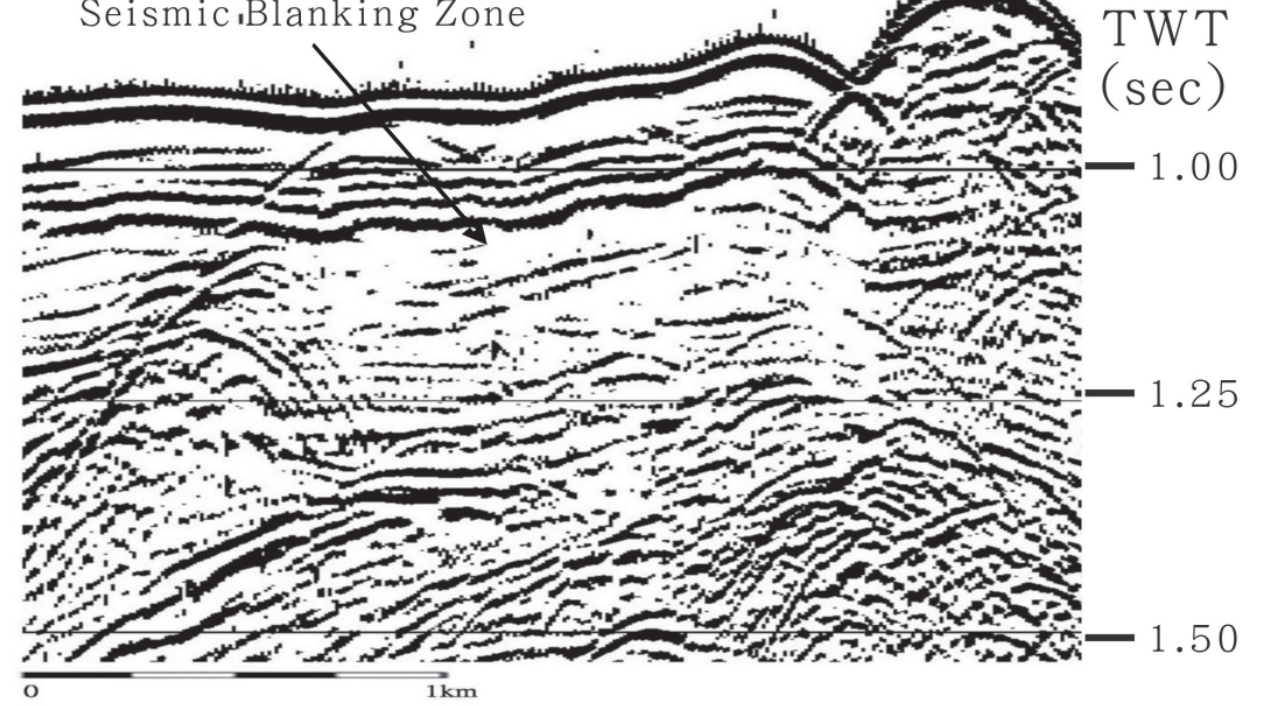

Fig. 4. Gassy sediment profiles of OR1-647 near the Kaoping Canyon, (a) chirp sonar image and (b) corresponding seismic reflection profile. 
(a)

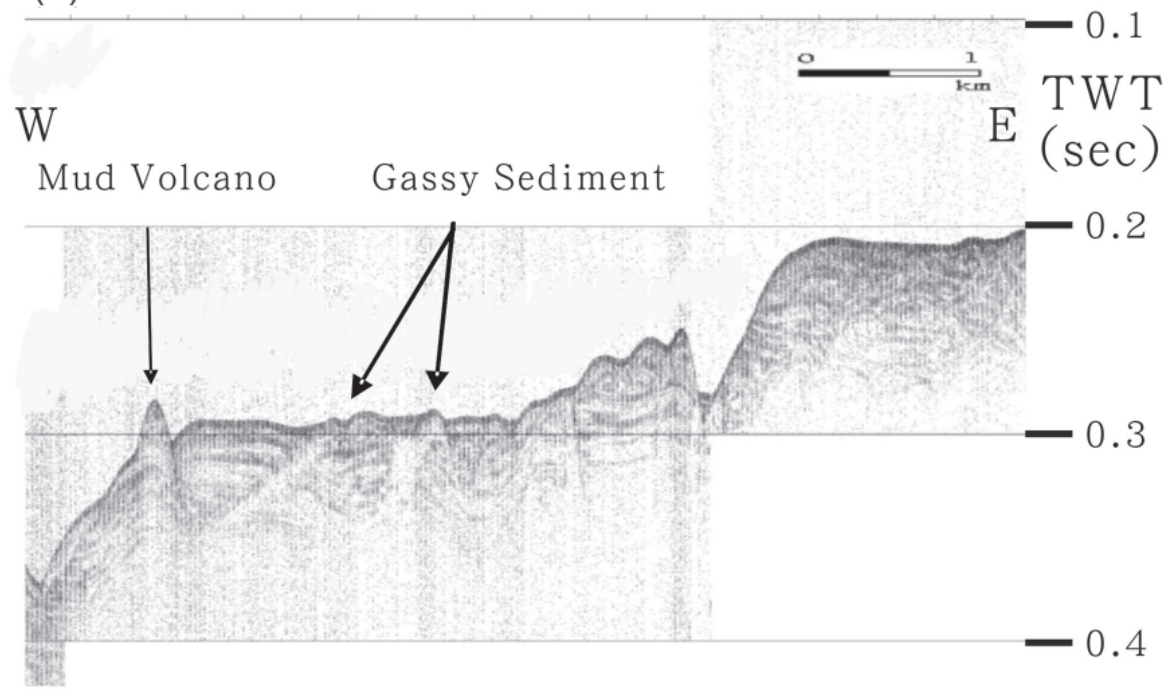

(b)

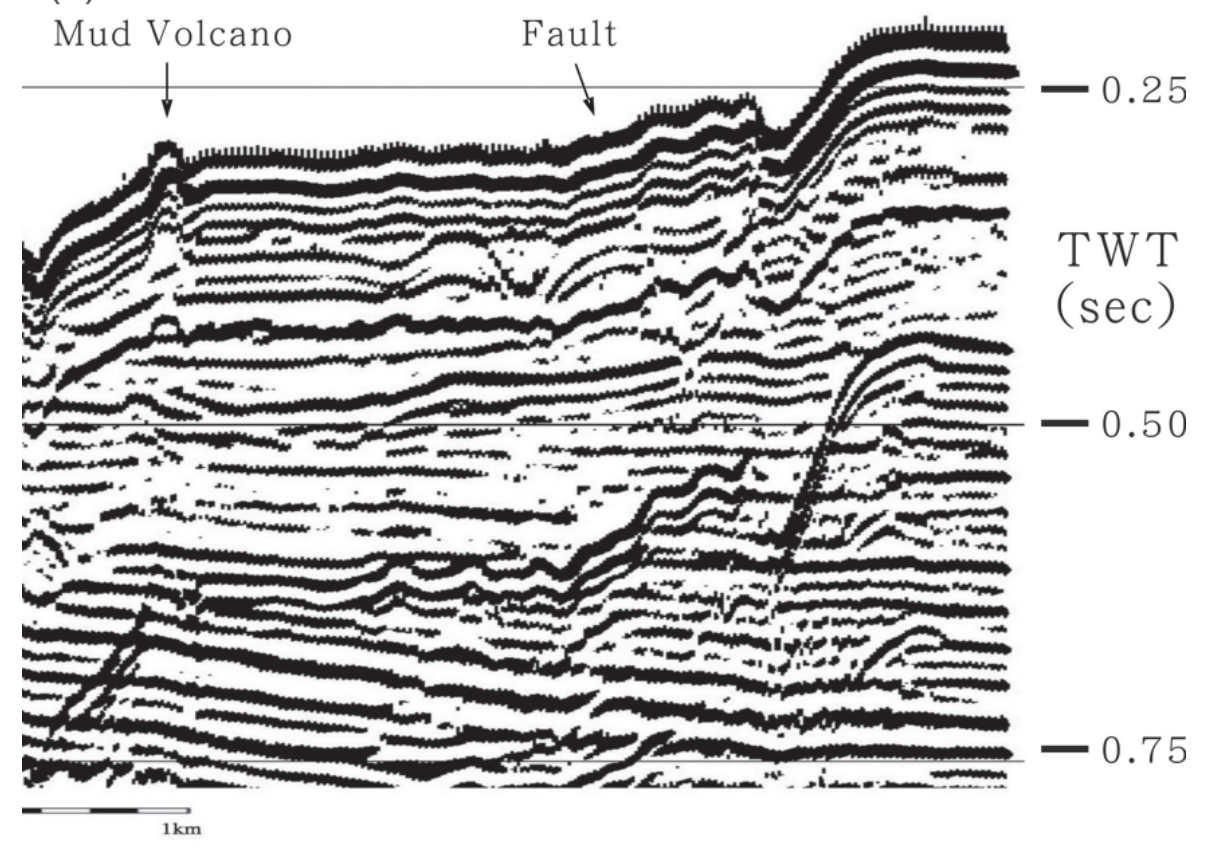

Fig. 5. Gassy sediment profiles of OR1-320 in the Kaoping Shelf, (a) $3.5 \mathrm{kHz}$ sub-bottom profile and (b) corresponding seismic reflection profile. 


\section{OBSERVATIONS}

\subsection{Distribution of Gassy Sediments and Mud Volcanoes}

In this study, we have identified more than 70 features that present acoustic characters of submarine mud volcanoes and gassy sediments. We mapped their locations (Fig. 2) and listed their occurrences in Table 1. It appears that gassy sediments and submarine mud volcanoes are patchily distributed in the study area off southwestern Taiwan.

In our observation, the acoustic characters and distribution patterns are somewhat different in the passive China continental margin province than in the accretionary wedge province. In the passive continental margin province, fewer gassy sediments and submarine mud volcanoes were found. The main group of submarine mud volcanoes is located on a ridge at $22^{\circ} 05^{\prime} \mathrm{N}$, $119^{\circ} 11^{\prime} \mathrm{E}$ in the lower South China Sea Continental Slope. There are a few individual mud volcanoes observed on the upper continental slope.

In the accretionary wedge province, a dense distribution of gassy sediments is observed on the Kaoping shelf and upper slope domain where water depths are shallower than 1000 meters. Seismic profilers reveal that they are located above mud diapir structures. These gassy sediments are aligned parallel to the axes of several mud diapiric ridges. Further away from the mud diapirs, less gassy sediments are observed. In addition, submarine mud volcanoes can be grouped into four main clusters. They are offshore Kaohsiung, adjacent to the Kaoping Submarine Canyon, near the head of the Fangliao Submarine Canyon, and along the Yung-An Lineament. Each cluster is composed of several to more than 10 submarine mud volcanoes.

\subsection{Accretionary Wedge Province}

We have identified gassy sediments at 25 sites in the accretionary wedge province offshore of southwestern Taiwan. They usually show acoustic blanking zones with irregular seafloor relief on SBP images (Figs. 4a, 5a). Their widths are from $80 \mathrm{~m}$ to several hundred meters and heights are $20-60 \mathrm{~m}$. Some acoustic blanking zones have reached the seafloor whilst others have not. On the corresponding seismic reflection images, both irregular seismic blanking zones and faults that could be the main paths of gas migration (Figs. 4b, 5b) are observed. This suggests that faults and fractures play an important role in the formation of gassy sediments.

The submarine mud volcanoes in the study area have different morphological appearance. The cluster offshore of Kaohsiung is composed of 10 - 15 linearly aligned mud volcanoes along the suggested offshore extension of the Chishan Fault. They appear in dome shape on $3.5 \mathrm{kHz}$ analog profiles (Fig. 6a). On $3.5 \mathrm{kHz}$ analog profiles, we could easily observe a feeder channel below the mud volcano (Fig. 6b).

There are several individual submarine mud volcanoes scattered adjacent to the Kaoping Submarine Canyon. The flanks of many mud volcanoes are steep. The tip of one mud volcano rises to over 34 meters above the seafloor (Fig. 7). This suggests that the viscosity of the mud is quite high. The different dip of the strata on either side of this mud volcano suggests that there may be a fault cut through the sedimentary layers and that fault also acts as the conduit for upward migrating fluids. 
Table 1. Occurrence of gassy sediments and mud volcanoes offshore of southwestern Taiwan.

\begin{tabular}{|c|c|c|c|c|}
\hline Latitude(N) & Longitude(E) & Location description & Type of observation & Data source \\
\hline 21.986700 & 119.662100 & PCMP & gassy sediments & OR1-719 \\
\hline 22.455300 & 119.709550 & PCMP & gassy sediments & OR1-719 \\
\hline 22.111300 & 119.801850 & Yung-An Lineament & gassy sediments & OR1-719 \\
\hline 22.391300 & 119.818250 & Yung-An Lineament & gassy sediments & OR1-735 \\
\hline 22.373000 & 119.859950 & Yung-An Lineament & gassy sediments & OR1-735 \\
\hline 22.383150 & 119.889150 & Yung-An Lineament & gassy sediments & OR1-735 \\
\hline 22.376350 & 119.909500 & Yung-An Lineament & gassy sediments & OR1-735 \\
\hline 22.284350 & 120.000800 & Offshore Kaohsiung & gassy sediments & OR1-647 \\
\hline 22.496900 & 120.054800 & Offshore Kaohsiung & gassy sediments & OR1-719 \\
\hline 22.532800 & 120.100150 & Offshore Kaohsiung & gassy sediments & OR1-719 \\
\hline 22.385900 & 120.106900 & Yung-An Lineament & gassy sediments & OR1-735 \\
\hline 22.450250 & 120.107550 & Yung-An Lineament & gassy sediments & OR1-735 \\
\hline 22.556800 & 120.108750 & Offshore Kaohsiung & gassy sediments & OR1-716 \\
\hline 22.425700 & 120.110800 & Yung-An Lineament & gassy sediments & OR1-647 \\
\hline 22.593500 & 120.169300 & Offshore Kaohsiung & gassy sediments & OR1-735 \\
\hline 22.306050 & 120.173150 & Offshore Kaohsiung & gassy sediments & OR1-647 \\
\hline 22.520450 & 120.174500 & Offshore Kaohsiung & gassy sediments & OR1-647 \\
\hline 22.475150 & 120.176700 & Offshore Kaohsiung & gassy sediments & OR1-647 \\
\hline 22.502950 & 120.186500 & Offshore Kaohsiung & gassy sediments & OR1-647 \\
\hline 22.421585 & 120.368900 & Kaoping SC & gassy sediments & OR1-601 \\
\hline 22.038300 & 120.375850 & Fangliao SC & gassy sediments & OR1-716 \\
\hline 22.144950 & 120.452750 & Fangliao SC & gassy sediments & OR1-716 \\
\hline 22.271600 & 120.524550 & Fangliao SC & gassy sediments & OR1-382 \\
\hline 22.273425 & 120.527000 & Fangliao SC & gassy sediments & OR1-382 \\
\hline 22.286195 & 120.541450 & Fangliao SC & gassy sediments & OR1-382 \\
\hline 22.148000 & 118.873167 & PCMP & mud volcanoes & OR1-764 \\
\hline 22.274050 & 118.957500 & PCMP & mud volcanoes & OR1-754 \\
\hline 22.001167 & 119.093800 & PCMP & mud volcanoes & OR1-764 \\
\hline 22.051600 & 119.112017 & PCMP & mud volcanoes & OR1-764 \\
\hline 22.048183 & 119.112133 & PCMP & mud volcanoes & OR1-764 \\
\hline 22.061950 & 119.117367 & PCMP & mud volcanoes & OR1-764 \\
\hline 22.049417 & 119.124533 & PCMP & mud volcanoes & OR1-764 \\
\hline 22.061617 & 119.137900 & PCMP & mud volcanoes & OR1-764 \\
\hline 22.704135 & 119.767900 & PCMP & mud volcanoes & OR1-329A \\
\hline 22.231950 & 119.803550 & Yung-An Lineament & mud volcanoes & OR1-754 \\
\hline 22.239150 & 119.806850 & Yung-An Lineament & mud volcanoes & OR1-735 \\
\hline 22.228750 & 119.812750 & Yung-An Lineament & mud volcanoes & OR1-735 \\
\hline 22.353950 & 119.859150 & Yung-An Lineament & mud volcanoes & OR1-735 \\
\hline
\end{tabular}


Table 1. (Continued)

\begin{tabular}{|c|c|c|c|c|}
\hline Latitude(N) & Longitude $(E)$ & Location description & Type of observation & Data source \\
\hline 22.314400 & 120.025950 & Offshore Kaohsiung & mud volcanoes & OR1-647 \\
\hline 22.483200 & 120.077850 & Offshore Kaohsiung & mud volcanoes & OR1-735 \\
\hline 22.396450 & 120.090400 & Offshore Kaohsiung & mud volcanoes & OR1-647 \\
\hline 22.509950 & 120.125300 & Offshore Kaohsiung & mud volcanoes & OR1-746 \\
\hline 22.575000 & 120.134450 & Offshore Kaohsiung & mud volcanoes & OR1-716 \\
\hline 22.554650 & 120.138850 & Offshore Kaohsiung & mud volcanoes & OR1-735 \\
\hline 22.463750 & 120.139200 & Offshore Kaohsiung & mud volcanoes & OR1-647 \\
\hline 22.579650 & 120.140100 & Offshore Kaohsiung & mud volcanoes & OR1-716 \\
\hline 22.565450 & 120.150600 & Offshore Kaohsiung & mud volcanoes & OR1-735 \\
\hline 22.614525 & 120.162865 & Offshore Kaohsiung & mud volcanoes & OR1-423 \\
\hline 22.313750 & 120.163400 & Offshore Kaohsiung & mud volcanoes & OR1-647 \\
\hline 22.309600 & 120.168650 & Offshore Kaohsiung & mud volcanoes & OR1-647 \\
\hline 21.558300 & 120.180350 & Offshore Kaohsiung & mud volcanoes & OR1-719 \\
\hline 22.388175 & 120.406300 & Kaoping SC & mud volcanoes & OR1-601 \\
\hline 22.380900 & 120.408100 & Kaoping SC & mud volcanoes & OR1-746 \\
\hline 22.183850 & 120.412800 & Fenliao SC & mud volcanoes & OR1-746 \\
\hline 22.390155 & 120.414650 & Kaoping SC & mud volcanoes & OR1-329A \\
\hline 22.378550 & 120.416750 & Kaoping SC & mud volcanoes & OR1-434 \\
\hline 22.205080 & 120.493300 & Fangliao SC & mud volcanoes & OR1-329B \\
\hline 22.280190 & 120.503950 & Fangliao SC & mud volcanoes & OR1-329A \\
\hline 22.256450 & 120.516250 & Fangliao SC & mud volcanoes & OR1-746 \\
\hline 22.256650 & 120.516450 & Fangliao SC & mud volcanoes & OR1-746 \\
\hline 22.259850 & 120.518950 & Fangliao SC & mud volcanoes & OR1-746 \\
\hline 22.260065 & 120.519400 & Fangliao SC & mud volcanoes & OR1-320 \\
\hline 22.260300 & 120.519700 & Fangliao SC & mud volcanoes & OR1-746 \\
\hline 22.252210 & 120.519900 & Fangliao SC & mud volcanoes & OR1-489 \\
\hline 22.266885 & 120.520150 & Fangliao SC & mud volcanoes & OR1-382 \\
\hline 22.261095 & 120.520500 & Fangliao SC & mud volcanoes & OR1-601 \\
\hline 22.259165 & 120.520600 & Fangliao SC & mud volcanoes & OR1-489 \\
\hline 22.264950 & 120.520600 & Fangliao SC & mud volcanoes & OR1-746 \\
\hline 22.269775 & 120.522200 & Fangliao SC & mud volcanoes & OR1-382 \\
\hline 22.264640 & 120.523000 & Fangliao SC & mud volcanoes & OR1-382 \\
\hline 22.266835 & 120.523350 & Fangliao SC & mud volcanoes & OR1-601 \\
\hline 22.265665 & 120.524650 & Fangliao SC & mud volcanoes & OR1-382 \\
\hline 22.267850 & 120.525150 & Fangliao SC & mud volcanoes & OR1-746 \\
\hline 22.268150 & 120.525350 & Fangliao SC & mud volcanoes & OR1-746 \\
\hline 22.266655 & 120.530350 & Fangliao SC & mud volcanoes & OR1-489 \\
\hline
\end{tabular}

SCS: South China Sea; OR1: R/V Ocean Research I; Passive continental margin province: PCMP; Submarine Canyon: SC. 
(a)

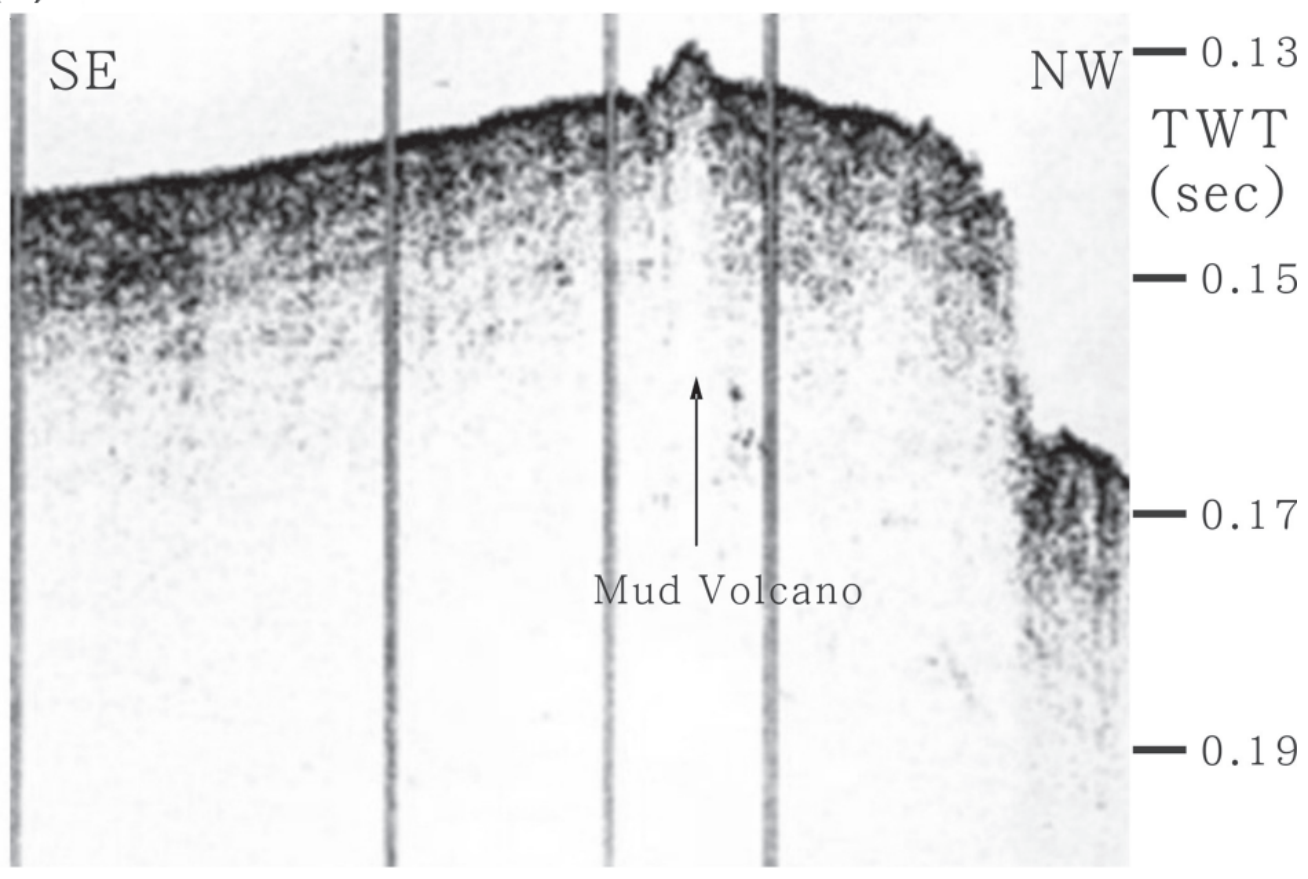

(b)

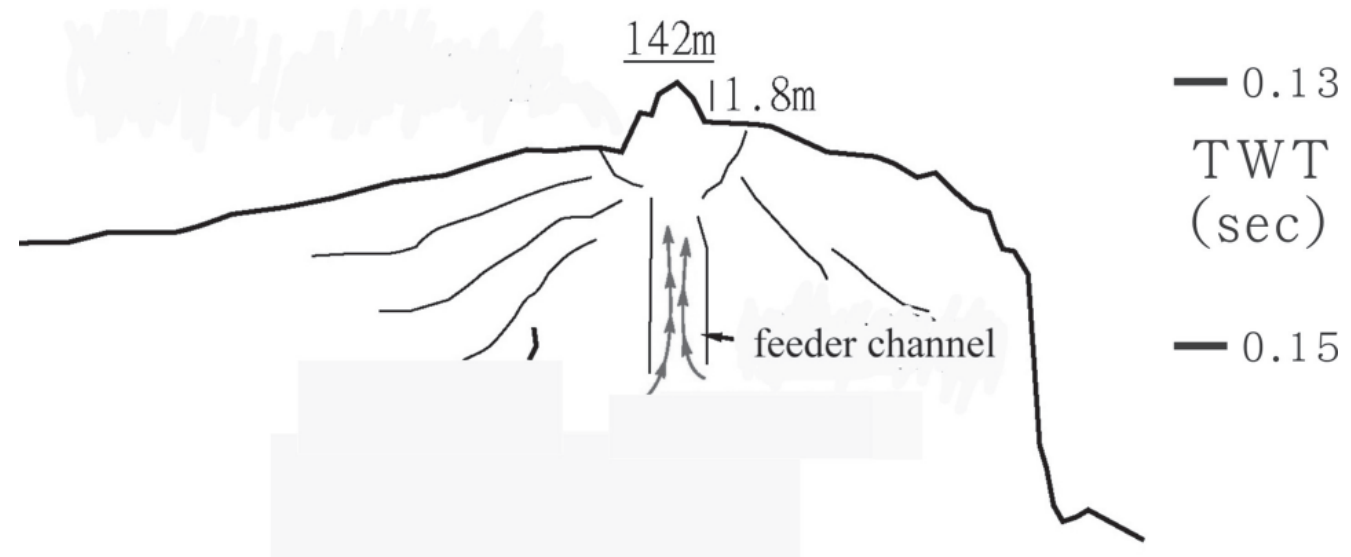

$-0.17$

Fig. 6. Mud volcano profiles of OR1-423 offshore of Kaohsiung, (a) $3.5 \mathrm{kHz}$ sub-bottom profile, (b) Interpreted $3.5 \mathrm{kHz}$ SBP. 
(a)

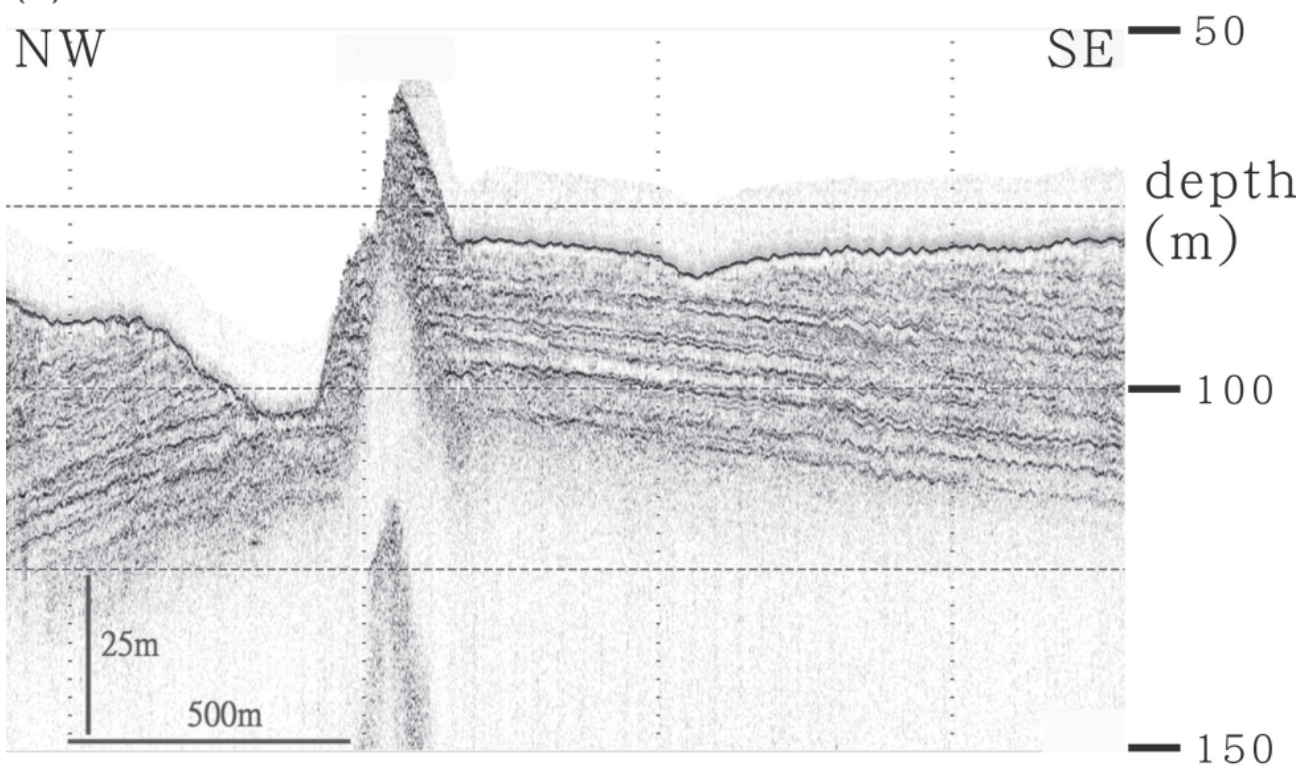

(b)

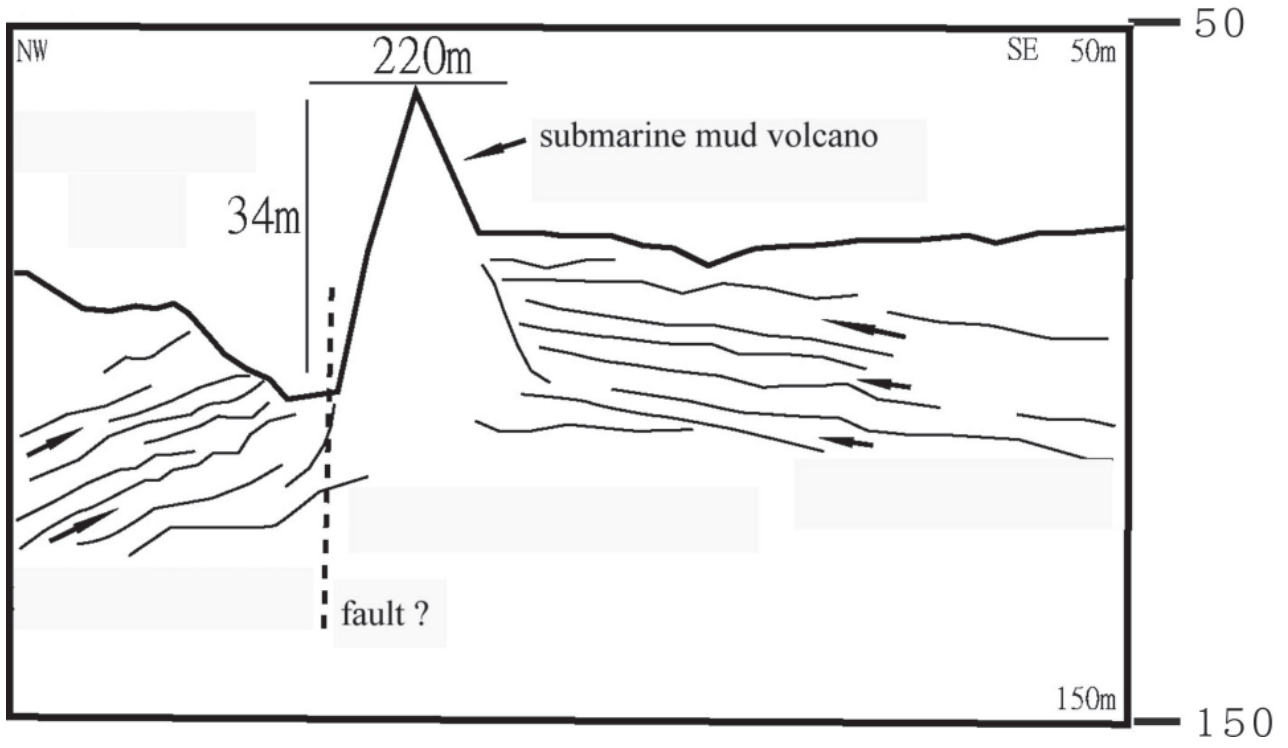

Fig. 7. (a) Image of a mud volcano on chirp sonar profile of OR1-746, (b) interpreted profile. 
A cluster of mud volcanoes is observed near the head of the Fangliao submarine canyon. There are nearly 20 mud volcanoes lying above a mud diapir. The cluster is located around $22^{\circ} 15^{\prime} \mathrm{N}, 123^{\circ} 30^{\prime} \mathrm{E}$ and the water depths range from 80 to $110 \mathrm{~m}$. These volcanoes are symmetrical in shape, with heights about $3-5 \mathrm{~m}$, and diameters of about $100 \mathrm{~m}$. In the middle reaches of the Fangliao submarine canyon, we could still observe some submarine mud volcanoes. Figure 8a shows a submarine mud volcano with a columnar acoustic blanking zone at $0.1 \sim 0.14 \mathrm{~s}$ TWT on a section of $3.5 \mathrm{kHz}$ SBP from cruise OR1-320. The acoustic blanking zone extends to the seafloor and formed a dome shape mound. The corresponding seismic reflection image (Fig. 8b) shows an acoustic chimney and disturbed reflectors of a feeder channel above a muddy diapir.

Figure 9a shows a cone-shaped mud volcano near the Yung-An Lineament where a channel-like acoustic blanking zone is obvious. The mud volcano has a width of about $200 \mathrm{~m}$ and a height of $3 \mathrm{~m}$. A mound was at the apex, and the fluids that pass through the conduit disturb the overlying sediments. Figure $9 \mathrm{~b}$ shows the seismic image of the same section. Enhanced reflections are observed from the sea floor to $2.35 \mathrm{~s}$ TWT where a strong reflector is present in the left half of the seismic reflection profile. The strong reflector is interpreted as a bottomsimulating reflector (BSR). The BSR seems to terminate against a west-dipping fault (Fig. 9d). We suggest that the fault could act as a conduit for the fluid to migrate upward to the surface, and thereby formed the mud volcano observed on the seafloor.

\subsection{Passive Continental Margin Province}

A group of submarine mud volcanoes are observed on a slope ridge about $22^{\circ} 05^{\prime} \mathrm{N}, 119^{\circ} 11^{\prime} \mathrm{E}$ in the upper portion of the South China Sea Continental Slope. There are also several submarine mud volcanoes scattered in the passive continental margin province. Figure 10 shows a cone-shape submarine mud volcano. Its height is about $20 \mathrm{~m}$ and diameter is about $345 \mathrm{~m}$. The chirp sonar signal could penetrate to only about $50 \mathrm{~m}$ below the seafloor in this area, thus it is hard to observe the fluid disturbance in the deeper part. In the corresponding seismic reflection profile, columnar chaotic signals could be observed below the submarine mud volcano, and the amplitudes of some reflections are strong. The columnar chaotic signals may be reflected from the feeder channel of the volcano.

\section{DISCUSSION}

Submarine mud volcanoes have been reported in many places around the world. In the Nankai trough and the Barbados accretionary wedge, mud volcanoes were discovered seaward of the deformation front (Milkov 2000). The distribution of submarine mud volcanoes offshore of southwestern Taiwan is somewhat different from these cases. First, two distribution patterns are observed in the study area: in the passive China continental margin province, most mud volcanoes are observed on slope ridges, especially in a centralized area around $22^{\circ} 05^{\prime} \mathrm{N}, 119^{\circ} 11^{\prime} \mathrm{E}$; while in the accretionary wedge province, approximately $70 \%$ of the mud volcanoes are distributed in the Kaoping Shelf and upper Kaoping Slope. Their origin may be linked to fluids escaping from mud diapirs below. In the deep water area (water depth $>1000 \mathrm{~m}$ ) 
(a)

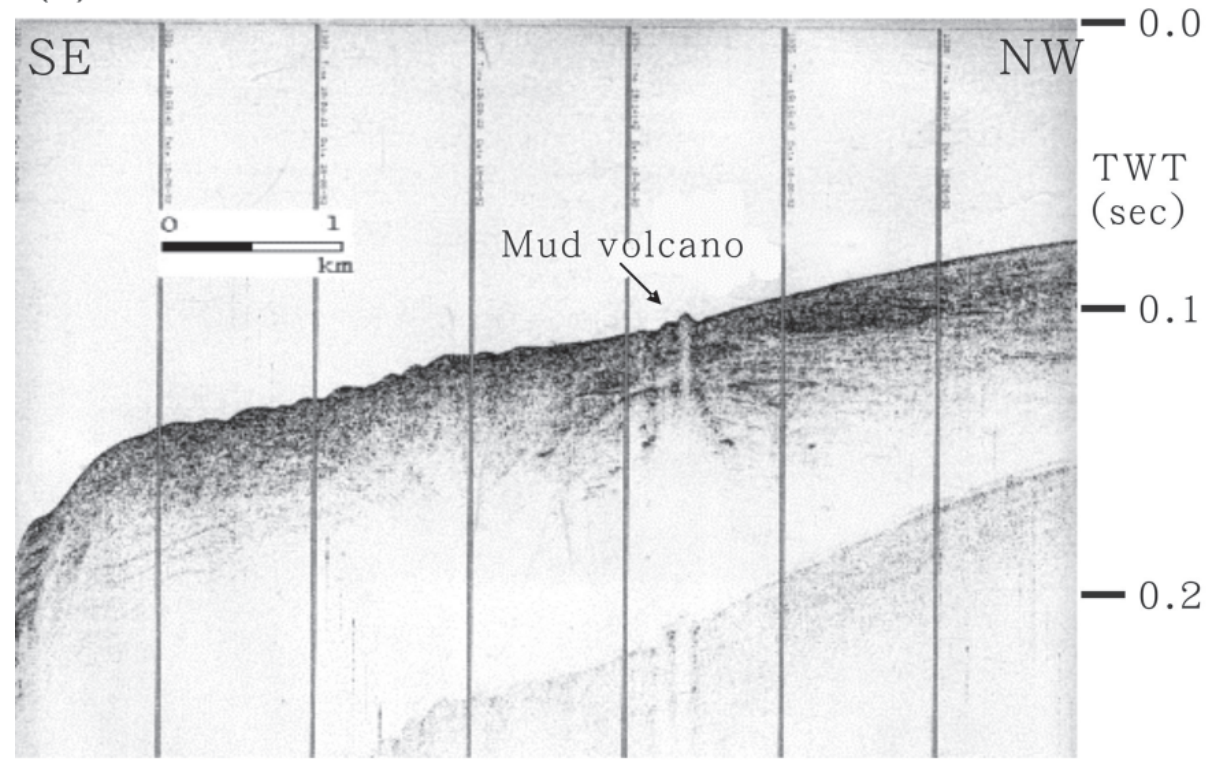

(b)

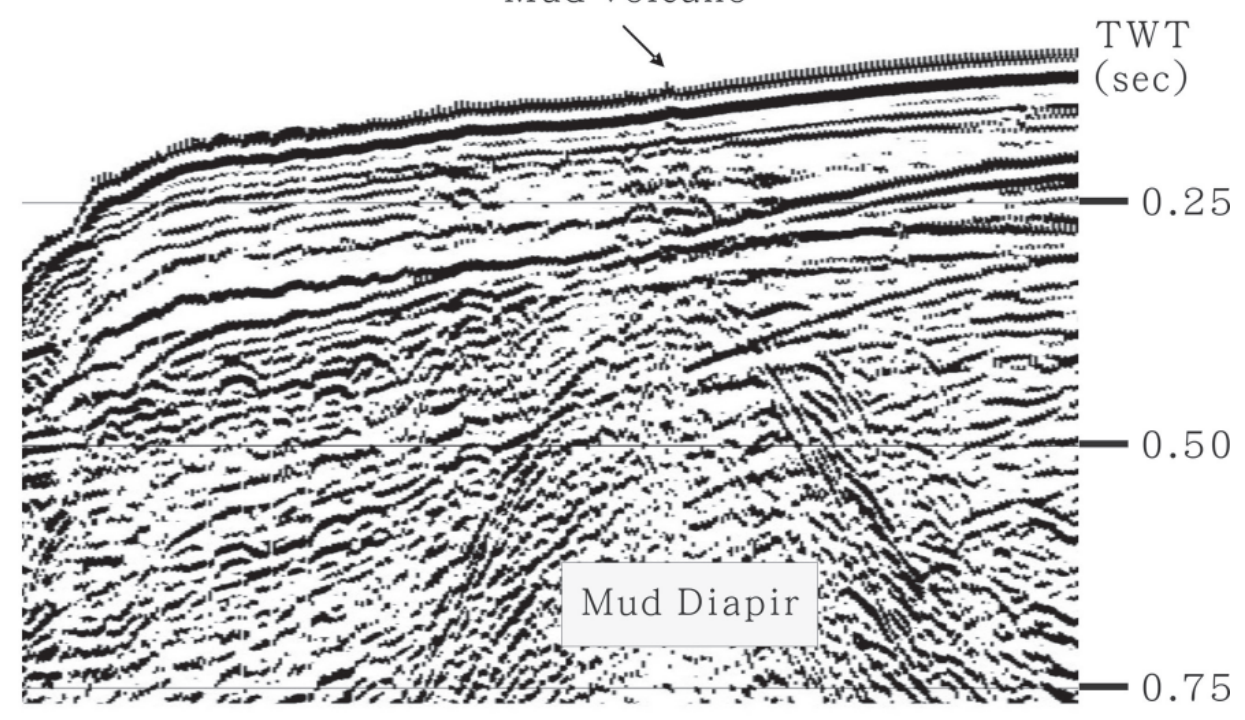

Fig. 8. Mud volcano profiles of OR1-320 near the head of the Fangliao Canyon. (a) $3.5 \mathrm{kHz}$ sub-bottom images and (b) the corresponding seismic reflection profile. 
(a)

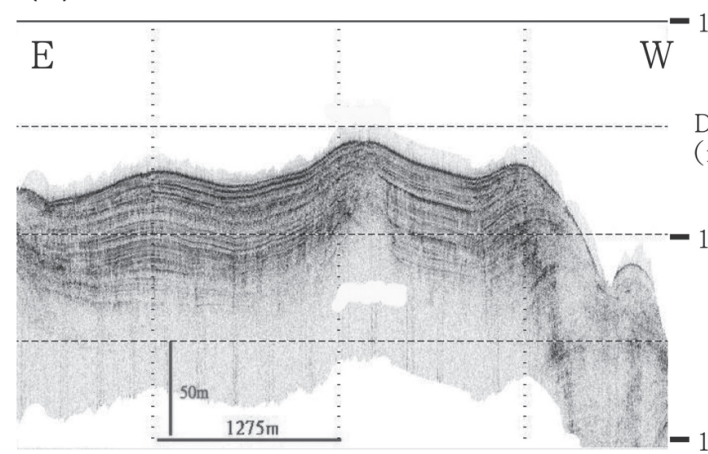

(b)

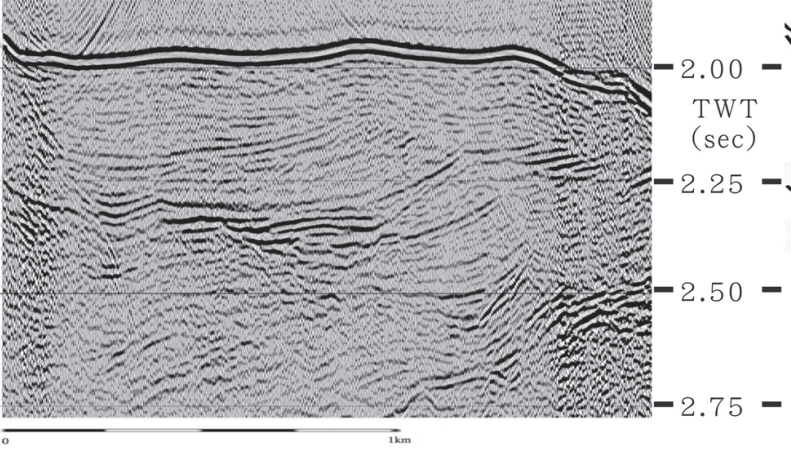

(c)

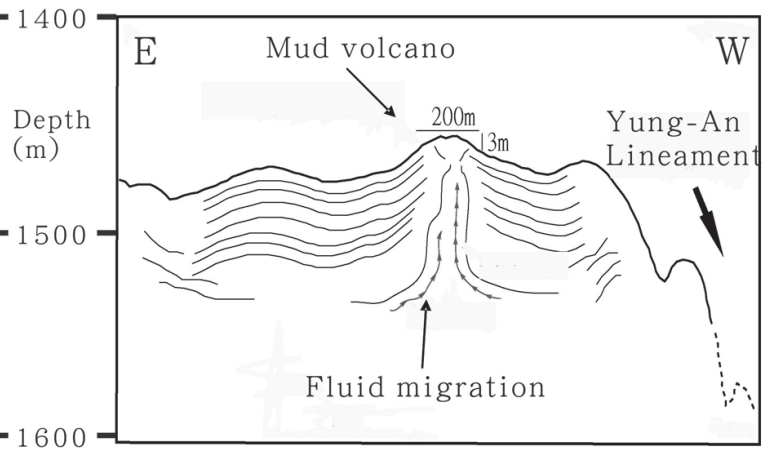

(d)

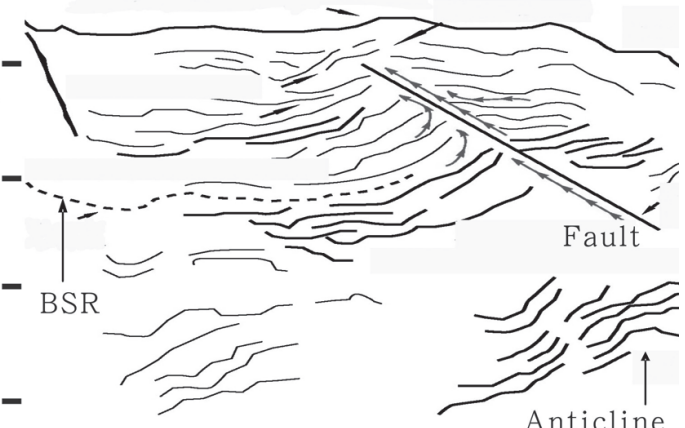

Fig. 9. Mud volcano profiles of OR1-735 near the Yung-An Lineament. (a) Chirp sonar profile, (b) corresponding seismic reflection profiles, (c) chirp sonar interpreted profile, and (d) interpreted seismic reflection profile.

of the accretionary wedge, mud diapiric features become fewer. Although fracture systems and thrust faults in the active accretionary wedge can act as migration pathways, we could observe only a few mud volcanoes in the deep water area.

The distribution of gassy sediments is also different between the accretionary wedge province and the passive China continental margin province. The number of identified features in the accretionary wedge margin is a lot more than that in the passive margin province. One of the reasons could be due to the ruggedness of the seafloor due to submarine erosion and less sediment accumulating on the SCS slope. Gassy sediments occur most frequently along fault zones. It is not easy to identify gassy sediments without the laminated strata in the submarine canyon area of the SCS slope.

The sizes of submarine mud volcanoes in the regions offshore of Barbados and in the Gulf of Mexico could reach several kilometers in diameter (Milkov 2000), while the sizes of mud volcanoes off southwestern Taiwan are relatively small with diameter widths in the ranges of 
(a)

(c)

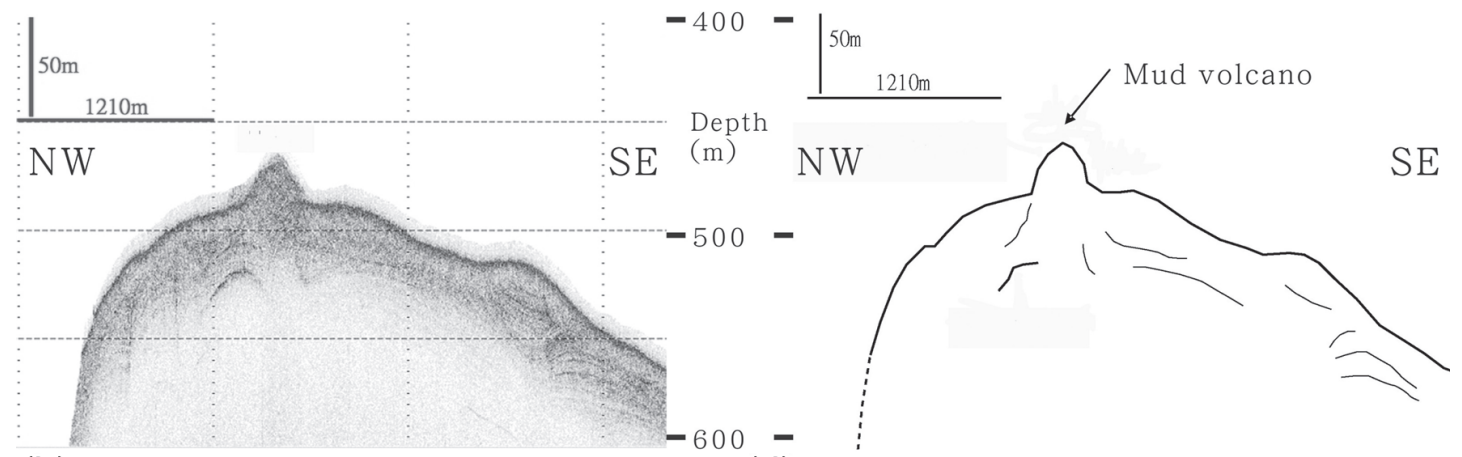

(b)

(d)
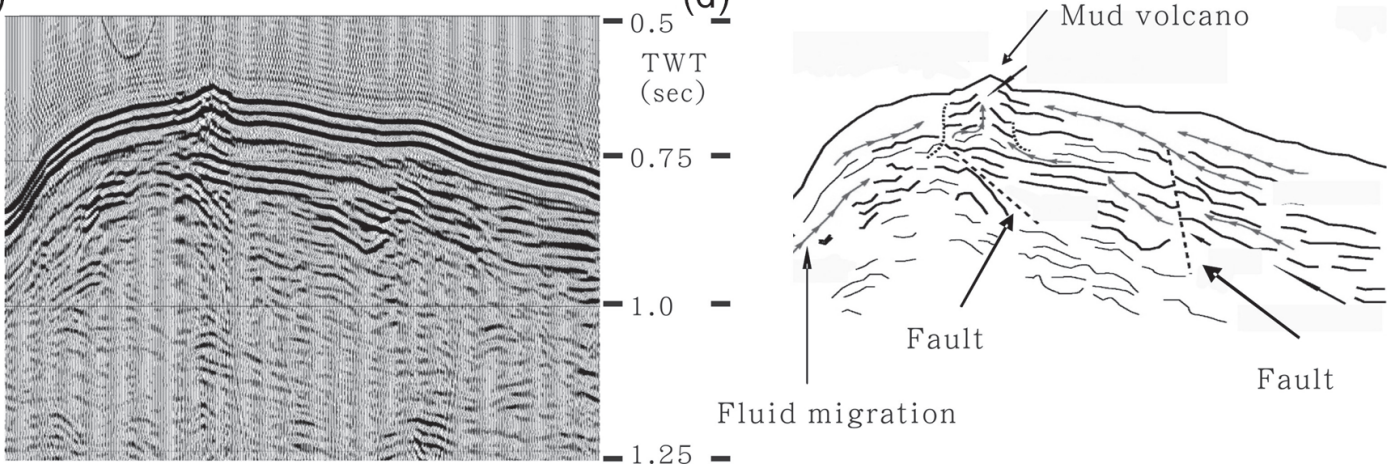

Fluid migration

Fig. 10. Mud volcano profiles of OR1-764 in the China Continental Slope. (a) chirp sonar profile, (b) corresponding seismic reflection profiles, (c) chirp sonar interpreted profile, and (d) interpreted seismic reflection profile.

several hundred meters. But we have identified up to 50 mud volcanoes in this study (Table 1).

The gassy sediments are usually accompanied by pockmarks (Dimitrov and Woodside 2003). Pockmarks are depressions which were formed by outbursts of high-pressure gases or fluids, and frequently occur in areas of fluid discharge. They need fine-grained sediments to support their structure and long existence. Off southwestern Taiwan, we have observed many patches of gassy sediments, but neither pockmark-like depression nor buried depression has been identified on the seafloor. We do not know whether no pockmark existed, or fast accumulation of sediments derived from the Taiwan mountain belt has covered the pockmarks. More detailed seafloor mapping, such as side-scan sonar or swath bathymetry surveying needs to be carried out to address this question.

High-resolution seismic reflection and SBP profiles show that some mud volcanoes have upward-dipping sedimentary strata around them, suggesting expulsion of thick fluid material. Brecciaed mudstones observed in the core samples collected off southwestern Taiwan (Chern 
1997) are a strong indication of submarine mud volcano eruptions. In addition, mud breccias are interbedded with turbidites, suggesting intermittent eruptions of mud volcanoes. Further evidence of active gas migration from deeper strata to the seafloor and into the seawater comes from geochemical investigation. High concentrations of methane in seawater and in seafloor sediments have been reported in many places offshore of southwestern Taiwan (Chuang et al. 2006; Yang et al. 2006; Chen and Tseng 2006), where mud volcanoes and/or gassy sediments are also observed.

The distribution of gassy sediments and submarine mud volcanoes is interwoven in our study. In some area, we could find both of them within a small distance (Fig. 5). This implies that their source could be the same, but the mechanisms to form gassy sediments and submarine mud volcanoes may be different. We suggest that fluid pressure in the strata may play an important role in the submarine mud volcano formation. Submarine mud volcanoes would be formed when the fluid pressure of the gases accumulated in a geological trap exceeds some threshold and causes an eruption, while gassy sediments are usually observed near existing faults and fractures which are good gas migration channels. The tectonic structures offshore of southwestern Taiwan are quite complex. We need more data to identify the relationship of gassy sediments and mud volcanoes.

\section{CONCLUSION}

The observation presented in this study clearly shows that gassy sediments and mud volcanoes are common features off southwestern Taiwan. We map the location of the gassy sediments and submarine mud volcanoes, and also measure their heights and widths. Their distribution could be grouped into five main clusters, four in the accretionary wedge province: offshore Kaohsiung, adjacent to the Kaoping Submarine Canyon, near the head of the Fangliao Submarine Canyon, and along the Yung-An Lineament, and one on top of a slope ridge in the passive continental margin province. Mud volcanoes located in the shelf and upper slope area where water depths are shallower than $1000 \mathrm{~m}$ in the arretionary wedge province could be related to mud diapiric activities. The formation of other mud volcanoes could the result of gas hydrate dissociation and the rising of high-pressure fluids along faults and fractures.

Acknowledgements We would like to thank the Captain and crew of the R/V Ocean Research 1 and the technical staff from the Ocean Researcher 1 Precious Instrument Center for their excellent support in collecting the seismic and chirp sonar data used in this study. We also thank Dr. P. Yin and an anonymous reviewer for their comments and suggestions that improved the manuscript. This study is supported by the Central Geological Survey, Ministry of Economic Affairs, ROC, under grants 5226902000-06-93-01 and 5226902000-05-94-01.

\section{REFERENCES}

Chen, C. T. A., and H. C. Tseng, 2006: Abnormally high $\mathrm{CH}_{4}$ concentrations in seawater at mid-depths on the continental slopes of the northern South China Sea. Terr. Atmos. Ocean. Sci., 17, 951-959. 
Chern, Y. C., 1997: Sedimentology of surface sediments off southwest Taiwan. Ph. D. Thesis, Natl. Taiwan Univ., Taiwan, 160 pp. (in Chinese)

Chuang, P. C., T. F. Yang, S. Lin, H. F. Lee, T. F. Lan, W. L. Hong, C. S. Liu, J. C. Chen, and Y. Wang, 2006: Extremely high methane concentration in bottom water and cored sediments from offshore southwestern Taiwan. Terr. Atmos. Ocean. Sci., 17, 903-920.

Covey, M., 1984: Lithofacies analysis and basin reconstruction, Plio-Pleistocene western Taiwan foredeep. Petrol. Geol. Taiwan, 20, 53-83.

Dimitrov, L. I., 2002: Mud volcanoes - the most important pathway for degassing deeply buried sediments. Earth-Sci. Rev., 59, 49-76.

Dimitrov, L., and J. Woodside, 2003: Deep sea pockmark environments in the eastern Mediterranean. Mar. Geol., 195, 263-276.

Fleischer, P., T. H. Orsi, M. D. Richardson, and A. L. Anderson, 2001: Distribution of free gas in marine sediments: a global review. Geo-Mar. Lett., 21, 103-122.

Huang, C. Y., W. Y. Wu, C. P. Chang, S. Tsao, P. B. Yuan, C. W. Lin, and K. Y. Xia, 1997: Tectonic evolution of accretionary prism in the arc-continent collision terrane of Taiwan. Tectonophysics, 281, 31-51.

Judd, A. G., G. Davies, J. Wilson, R. Holmes, G. Baron, and I. Brydon, 1997: Contributions to atmospheric methane by natural gas seepage on the UK continental shelf. Mar. Geol., 137, 175-189.

Lacombe, O., F. Mouthereau, J. Angelier, and B. Deffontaines, 2001: Structural, geodetic and seismological evidence for tectonic escape in SW Taiwan. Tectonophysics, 333, 323-345.

Lee, S. H., and S. K. Chough, 2003: Distribution and origin of shallow gas in deep-sea sediments of the Ulleung Basin, East Sea (Sea of Japan). Geo-Mar. Lett., 22, 204-209.

Liu, C. S., I. L. Huang, and L. S. Teng, 1997: Structure features off southwestern Taiwan. Mar. Geol., 137, 305-319.

Liu, C. S., S. Y. Liu, S. E. Lallemand, N. Lundberg, and D. Reed, 1998: Digital elevation model offshore Taiwan and its tectonic implications. Terr. Atmos. Ocean. Sci., 9, 705-738.

Liu, C. S., B. Deffontaines, C. Y. Lu, and S. Lallemand, 2004: Deformation patterns of an accretionary wedge in the transition zone from subduction to collision offshore southwestern Taiwan. Mar. Geophys. Res., 25, 123-137.

Liu, C. S., P. Schnürle, Y. Wang, S. H. Chung, S. C. Chen, and T. H. Hsiuan, 2006: Distribution and characters of gas hydrate offshore of southwestern Taiwan. Terr. Atmos. Ocean. Sci., 17, 615-644.

MacDonald, I. R., W. W. Sager, and M. B. Peccini, 2003: Gas hydrate and chemosynthetic biota in mounded bathymetry at mid-slope bydrocarbon seeps: Northern Gulf of Mexico. Mar. Geol., 198, 133-158.

Milkov, A. V., 2000: Worldwide distribution of submarine mud volcanoes and associated gas hydrates. Mar. Geol., 167, 29-42.

Milliman, J. D., and S. J. Kao, 2005: Hyperpycnal discharge of fluvial sediment to the ocean: impact of super-typhoon Herb (1996) on Taiwanese rivers. J. Geol., 113, 503-516.

Oung, J. N., C. Y. Lee, C. S. Lee, and C. L. Kuo, 2006: Geochemical study on hydrocarbon gases in seafloor sediments, southwestern offshore Taiwan - implications in the potential occurrence of gas hydrates. Terr. Atmos. Ocean. Sci., 17, 921-931. 
Sassen, R., S. L. Losh, L. Cathles III, H. H. Roberts, J. K. Whelan, A. V. Milkov, S. T. Sweet, and D. A. Defreitas, 2001: Massive vein-filling gas hydrate: relation to ongoing gas migration from the deep subsurface in the Gulf of Mexico. Mar. Petrol. Geol., 18, 551-560.

Water Resources Bureau, 1998: Hydrological Year Book of Taiwan, Republic of China, 1997. MOEA, ROC, $378 \mathrm{pp}$.

Yang, T. F., P. C. Chuang, S. Lin, J. C. Chen, Y. Wang, and S. H. Chung, 2006: Methane venting in gas hydrate potential area offshore of SW Taiwan: evidence of gas analysis of water column samples. Terr. Atmos. Ocean. Sci., 17, 933-950.

Yang, T. F., G. H. Yeh, C. C. Fu, C. C. Wang, T. F. Lan, H. F. Lee, C. H. Chen, V. Walia, and Q. C. Sung, 2004: Composition and exhalation flux of gases from mud volcanoes in Taiwan. Environ. Geol., 46, 1003-1011.

Yilmaz, O., 1987: Seismic data processing: Processing, inversion, and interpretation of seismic data, Soc. Explor. Geophys., Tulsa, 2027 pp.

Yu, H. S., and G. S. Song, 2000: Submarine physiographic features in Taiwan region and their geological significance. J. Geol. Soc. China, 43, 267-286.

Yun, J. W., D. L. Orange, and M. E. Field, 1999: Subsurface gas offshore of northern California and its link to submarine geomorphology. Mar. Geol., 154, 357-368.

Chiu, J. K., W. H. Tseng, and C. S. Liu, 2006: Distribution of gassy sediments and mud volcanoes offshore southwestern Taiwan. Terr. Atmos. Ocean. Sci., 17, 703-722. 